This carefully-edited volume gives invaluable insights into Gendelev's poetic and ideological transformations. It invites us to discover a poet whose metaphysical skepticism is radical and whose playing with language, puns, phonetic structures, and semantic ambivalences are virtuous. Hopefully, further editions of this kind will help us to explore the vibrant scene of contemporary Russian-Israeli literature.

SABINE KOLLER

University of Regensburg

\title{
The Sixth Sense of the Avant-Garde: Dance, Kinaesthesia and the Arts in Revolu- tionary Russia. By Irina Sirotkina and Roger Smith. London: Bloomsbury Press, 2017. xii, 217 pp. Notes. Bibliography. Index. Illustrations. $£ 63.00$, hard bound. doi: 10.1017/slr.2018.268
}

The joy of movement and profound appreciation for the human body's expressiveness underlie this book by Irina Sirotkina and Roger Smith. An expanded translation of Sirotkina's Shestoe chuvstvo avangarda: Tanets, dvizhenie, kinesteziia $v$ zhizni poetov $i$ khudozhnikov (2014), this study offers an invigorating exploration of the upsurge in kinaesthetics that permeated early twentieth-century Russian culture. As the two authors proffer, sustained emphasis on modern movement resulted in art and ideas that celebrated both the physical and aesthetic potential of the human body.

While Nicoletta Misler and John Bowlt have over the years established the Russian avant-garde's embrace of dance as material ripe for scholarly investigation, Sirotkina and Smith provide a much-needed historical overview and far-reaching theoretical approach to the abundance of dance and, more broadly, kinaesthesia in Russian avant-garde culture. Defying the notion that everyday human motion is somehow "nonserious," Sirotkina and Smith expand upon a wide array of critical theories and performance studies scholarship to underscore the predominance of dance and other manifestations of human movement for artists and thinkers in revolutionary Russia. Forming a fluid partnership to expand Sirotkina's initial scholarship, Sirotkina and Smith probe the era's abundance of human motion in compelling fashion.

In their first chapter, Sirotkina and Smith explore the so-called "sixth sense," honing in on the haptic, that is, the era's emphasis on touch and an awareness of everyday reality that came about through enhanced movement. At the theoretical heart of such an approach is the work of Edmund Husserl, who linked bodily movement to phenomenological awareness, and Maurice Merleau-Ponty, who ascribed a psychological "attitude" to voluntary motion of the human body. Emphasizing that "kinaesthetic sensations were important for artists in all aspects of their lives" (40), the authors focus on "knowledge how" and "knowledge that," philosophical terminology that helps differentiate conscious kinaesthetic action from automatic proprioceptive movement.

In subsequent chapters, Sirotkina and Smith draw upon a diverse range of examples to tell their story and to underscore the kinaesthesia pulsating through Russian and early Soviet culture. First off is the abstract art of Vasily Kandinsky, whose work drew on not only the Dionysian "transvaluation of values" (46) espoused by Friedrich Nietzsche, but also those spiritual vibrations evoked by poet (and composer) Mikhail Matiushin. A "higher sensitivity" (50) arises through the abundant kinaesthesia 
and synaesthesia underpinning Kandinsky's art. The language of movement and a return to the Hellenic ideals of Ancient Greece, Sirotkina and Smith explain, emerged in various pre-revolutionary Russian settings, such as the Heptachor studio in Petrograd, Faddei Zelinsky's Institute of the Living Word, and the Institute of Harmonic Development, where George Gurdjieff promoted the rhythmic practices of Émile Jaques-Dalcroze and the theatrical system of Aleksandr and Jeanne Salzmann. Kinaesthesia also provided a conceptual springboard for symbolists like Andrey Belyi, who incorporated rhythmical gestures into his verse. "Bely's body and his language formed a whole" (82), the authors contend.

In addition to providing a new kinaesthetic perspective on the work of artists not normally associated with the "sixth sense," Sirotkina and Smith venture into more familiar territory when discussing the creative union of American dancer Isadora Duncan and poet Sergei Esenin or Vsevolod Meyerhold's biomechanical exercises for actors, but even here the research and analysis prove quite original. Less convincing, however, is the authors' discussion of Vladimir Maiakovskii's verse, for here they rely too conspicuously on biographical conjecture: "The habitués of cafes tangoed side by side with the professionals and Mayakovsky, we imagine, was to be found amongst them" (128). But Sirotkina and Smith soon find themselves on surer ground when delving into Viktor Shklovskii's experimental attempts to undermine the automatization of everyday language-and movement-that stemmed, the authors suggest, from the formalist's interest in wrestling, gymnastics, and gesture.

Sirotkina and Smith, it should be noted, have melded together many forms of modern movement, thus creating a slightly lopsided study that dwells mostly on dance but also devotes significant attention to poetry, theater, and sports. Yet such flexibility ultimately serves Sirotkina and Smith well, as they waltz-or foxtrot or tango, as the case may be-their way through the myriad examples of kinaesthetic art in revolutionary Russia. The era's turn to the body and "knowing how," they explain in their concluding chapter, represented "an expression of desire for individual agency" (169). This knowledge and individual expressivity would have a profound impact on twentieth-century art and society.

TIM HARTE

Bryn Mawr College

\section{Vagabonding Masks: The Italian Commedia Dell'arte in the Russian Artistic Imagination. By Olga Partan. Brighton, Mass.: Academic Studies Press, 2017. 290 pp. Bibliography. Illustrations. Index. \$79.00, hard bound.} doi: 10.1017/slr.2018.269

For most scholars of Russian literary and cultural history, the first set of associations with the Italian commedia dell'arte tradition relate to modernism: from conspicuous examples, such as Aleksandr Blok's Balaganchik, to subtle references as in Belyi's Petersburg (the terrorist Lippanchenko is likened to a hunchback Pierrot), the commedia dell'arte stock characters populate modernist plays, paintings, poems, and works of prose. While the Silver Age's engagement with figures from commedia dell'arte is well studied, until now there has been virtually no consideration of how this vital genre of improvisational performance art ramified in earlier and later periods of Russian culture. Olga Partan's Vagabonding Masks remedies this scholarly lacuna by tracing the history of the Italian theatrical tradition in Russia starting in the early eighteenth century and extending up to the present moment. In her chronologically-organized 